\title{
Polymers Encapsulated Aspirin Loaded Silver Oxide Nanoparticles: Synthesis, Characterization and its Bio-Applications
}

(Aspirin Terkurung Polimer Dimuatkan Nanozarah Perak Oksida: Sintesis, Pencirian dan Bio-Penggunaan)

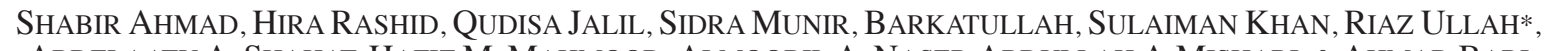
AbdelaAty A. Shahat, Hafiz M. Mahmood, AlmoQbil A. NAser Abdullah A-Mishari \& Ahmad Bari

\section{ABSTRACT}

Simple, facile and cost effective approach is used for the synthesis of Aspirin based silver oxide nano-particles (SONPS) by chemical wet method. The synthesized SONPs were loaded with Aspirin to form Asp-SONPs, which was confirmed with the help of UV spectroscopy. Characterization was done using spectroscopy techniques FTIR, SEM, TEM and XRD. Antimicrobial assay of Asp-SONPs were carried out against six bacterial strains (E. coli, Protues, Vibrio, Citrobacter, Enterobacter, $\mathrm{S}$. aureus) and fungal strains (Curvularia, Alternaria, Rhizopus, Aspergillus, Helmithosporium, Paecilomyces) by well diffusion method which confirmed its potential application as an antimicrobial agent. Asp-SONPS-PVA also displayed highest insecticidal activity against both tested insects (Tribolium casterium and Callosobruchus chinensis) having LC value of 15.917, and 37.6365 and highest percent mortality at 1000 ppm was 67\%, and 73\%, respectively. PVA coated SONPS displayed encouraging phytotoxicity when exposed to allopathic, where Asp-SONPS coated PVA give excellent anthelmintic activity by killing or paralyzing all the species (earthworm) at 1000 ppm.

Keywords: Antimicrobial; antioxidant; aspirin; insecticidal; nanoparticles

\section{ABSTRAK}

Pendekatan yang mudah dan berkesan digunakan untuk mensintesis Aspirin berasaskan nanozarah perak beroksida (SONPS) dengan menggunakan kaedah kimia basah. SONPs tersintesis dengan Aspirin untuk membentuk Asp-SONPs, yang dikenal pasti dengan menggunakan Spektroskopi UV. Pencirian telah dilakukan menggunakan teknik spektroskopi iaitu FTIR, SEM, TEM dan XRD. Cerakinan antimikrob Asp-SONPS telah dijalankan terhadap enam strain bakteria (E. coli, Protues, Vibrio, Citrobacter, Enterobacter, S. aureus) dan strain kulat (Curvularia, Alternaria, Rhizopus, Aspergillus, Helmithosporium, Paecilomyces) dengan menggunakan kaedah resapan yang mengesahkan aplikasinya yang berpotensi sebagai agen antimikrob. Asp-SONPs-PVA juga menunjukkan aktiviti insektisid yang tertinggi terhadap kedua-dua serangga yang diuji (Tribolium casterium dan Callosobruchus chinensis) yang mempunyai nilai LC ${ }_{50}$ iaitu 15.917 dan 37.6365 dan peratus kematian tertinggi pada 1000 ppm masing-masing adalah 67\% dan 73\%. SONPs bersalut PVA menunjukkan kefitotoksikan menggalakkan apabila terdedah kepada alopati dengan Asp-SONPs bersalut PVA memberi aktiviti antelmin cemerlang dengan membunuh atau melumpuhkan semua spesies (cacing tanah) pada 1000 ppm.

Kata kunci: Antimikrob; antioksidan; aspirin; insektisid; nanozarah

\section{INTRODUCTION}

Lately, nanotechnology has been thriving as an emerging science due to its immense biological applications. Nanotechnology deals with nano particles in which at least two of its dimension is in nano range. The properties of nanoparticles rely on the size, shape, crystallinaity, structure and surface morphology. Small size and high surface area are characteristics that give nanoparticles its unique chemical and physical properties. Nanoparticles besides its use as a potential therapeutic agent in antiinflammatory, antibacterial, antiviral, anticancer processes it has also been successfully employed in the field of agriculture, cosmetics, textile, food, and chemical sensing. Silver oxide nanoparticles are widely used as an oxidation catalyst in chemical reactions (Choi et al. 2016). Enhanced and unique properties of AgONPs are attributed with nano- size of the material. There are large numbers of physical, chemical and biological methods used for the synthesis of NPs. One of the simplest method used being the chemical wet method. In this process metal or metal oxide is reduced to its corresponding ion by a reducing agent in an organic solvent. A capping agent or a stabilizer is used to coat nanoparticle such as polymer or surfactant which will control the size and prevent the agglomeration, oxidation of the intrinsically hydrophobic nanoparticles. Therefore, it is worthy to prepare $\mathrm{Ag}_{2} \mathrm{O}$ nanoparticles for its numerous applications through simple chemical modification (Galya et al. 2008; Gurunathan et al. 2013).

Aspirin (Figure 1) also known as acetyl salicylic acid is drug used to treat pain, fever, or inflammation. Aspirin is also used long-term to help prevent heart attacks and blood clots, in people at high risk (Chiguvare et al. 2016). Its uses 
are also very particular in certain types of cancer. Aspirin is a non-steroidal anti-inflammatory drug (NSAID) and works similar to other NSAIDs but also suppresses the normal functioning of platelets. It is one of the most widely used medications globally and is the most effective and safe medicines needed in a health system (Ahmad et al. 2014; Rafique et al. 2016). Recently, there has been increasing interest in the synthesis of nano-particle using different methods which are broadly classified as physical and chemical methods and biosynthesis using microorganisms (Hosseinpour et al. 2014; Yong et al. 2013). To the best of our knowledge, there have been no reports of synthesis of aspirin based silver oxide nanoparticle. The main objective of this paper was to suggest a facile cheap and effective method for the synthesis of biocompatible, pharmacologically important as AgONP and to show its biological activities including antimicrobial, anticancer, antioxidant, anthelmintic, pytotoxic and insecticidal activities.

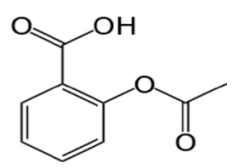

FIGURE 1. Structure of aspirin

\section{MATERIALS AND METHODS}

\section{MATERIALS}

Aspirin based silver oxide nanoparticles are synthesized using urea (supplied by BDH Laboratory components Poole, Bh15 1TD, England), salt of silver nitrate $\left(\mathrm{AgNO}_{3}\right), \mathrm{NaBH} 4$, soluble starch and polyvinyl alcohol (PVA) are (supplied by Sigma Aldrich Inc.). Aspirin and ethanol $\left(\mathrm{C}_{2} \mathrm{H}_{5} \mathrm{OH}\right)$ were bought from Merck. The water used throughout this experiment was distilled water. All glassware's have been properly washed with distilled water and dried in oven before use.

\section{SYNTHESIS OF ASPIRIN BASED SILVER OXIDE NANOPARTICLE}

Silver oxide nano-particles were synthesized by wet chemical method (Fang et al. 2005) where in this method, AgNPs were synthesized by using $\mathrm{NaBH} 4$ as reducing agent. An aqueous solution of trisodium citrate $(0.5 \mathrm{~mL}, 6$ $\mathrm{mM}$ ) was added into a flask containing $50 \mathrm{~mL}$ of deionized water, and then, an aqueous solution of $\mathrm{AgNO} 3$ (1 mL, $1 \mathrm{mM}$ ) was added. Freshly prepared $\mathrm{NaBH} 4$ aqueous solution $(0.5 \mathrm{~mL}, 10 \mathrm{mM})$ was quickly added, and the suspension immediately turned a light yellow color. After $10 \mathrm{~s}$, the suspension changed to a darker yellow or brown color after reaction had proceeded for another $20 \mathrm{~s}$. The particles were washed to remove any suspended impurities and to neutralize the solution with deionized water. The sample was then dried in oven at $100^{\circ} \mathrm{C}$ for $1 \mathrm{~h}$. The dried form precipitate of silver oxide nano-particles (SONPS) was grinded and then calcinated in furnace for $4 \mathrm{~h}$ to obtain 10 $\mathrm{g}$ of silver oxide nano-particles (SONPs) around $300^{\circ} \mathrm{C}$. Two separate solutions of SONPs $(2 \mathrm{~g})$ and aspirin $(3 \mathrm{~g})$ were prepared in ethyl alcohol. Aspirin solution was added drop wise to the SONPS solution which was kept on stirring at room temperature. Stirring was done continuously for $2 \mathrm{~h}$. The synthesized mixture was then subjected to sonication for $1 \mathrm{~h}$ and centrifuged at $6000 \mathrm{rpm}$. Then, the supernatant was removed and the residue of Asp-SONPs was collected and dried at room temperature. The dried As-SONPs amount was found to be $4.2 \mathrm{~g}$. The As-SONPs product was then subjected to UV-visible spectroscopy in order to determine its encapsulation efficiency. This resulted in the formation of functionalized Aspirin based silver nano-particle. The stabilization of these SONPs was achieved by the use of biocompatible polymers, polyvinyl and starch which acts as capping agents. $0.9 \mathrm{~g}$ of As-SONPs dissolved in ethanol and each coating material solution was prepared $2.5 \% \mathrm{w} / \mathrm{w}$ in de-ionized water, and added drop wise to solution of Asp-SONPs with constant stirring. When the whole coating material added to the sample then the reaction was stopped and dried at room temperature. Aspirin functionalized silver oxide nanoparticles was coated with two different coating materials namely Polyvinyl alcohol and soluble starch. Total amount of Asp-SONPS-PVA procured was found to be $1 \mathrm{~g}$ while As-SONPs-St procured was found to be $0.9 \mathrm{~g}$. The $\mathrm{pH}$ of the solution was controlled with $\mathrm{NaOH}$ at $\mathrm{pH} 9$ 10. Samples were taken after a constant interval of time.

\section{CHARACTERIZATION}

Purity, composition, structure and characterization of NPs was done using FTIR and XRD analysis which was accomplished by the use of 3040/60X'Pert seasoned diffractometer. Toes-IR spectra have been recorded with a shimadzu IR-460 spectrophotometer. Ultra violet visible spectroscopy (UV-Vis) was used to determine the optical properties of synthesized nanoparticles.

\section{BIOLOGICAL ACTIVITIES}

Antibacterial Activity Bacterial strains were cultured 24 $\mathrm{h}$ prior to its use. In the present study, antibacterial activity was determined for six pathogenic bacteria obtained from department of botany, Islamia College Peshawar. The antibacterial activity of synthesized nanoparticles i.e. SONPs, Asp-SONPs, Aspirin, PVA-Asp-SONPs and St-AspSONPs was determined using agar well diffusion technique (Balouiri et al. 2016). Nutrient agar plates were used under sterilized condition $\left(137^{\circ} \mathrm{C}\right.$ for $\left.15 \mathrm{~min}\right)$, after cooling the molten agar to $40^{\circ} \mathrm{C}$ agar wells were made and bacterial streaks were introduced on surface of solidified agar by sterilized cotton swab. Different concentrations of samples were introduction in comparison to the control where the zone of inhibition of all samples was calculated after $24 \mathrm{~h}$. Zone of inhibition of NPs was determined using diameter in triplicate, mean, SEM and also the percent growth inhibition. Six pathogenic bacteria Escherichia coli (gram 
positive), Staphyllococcus aureus (gram negative) Proteus vulgaris, Citrobacter freundii, Enterobacter aerogenes, and Vibrio cholera were used at four different concentrations $(50,100,150 \& 200 \mathrm{mg} / \mathrm{mL})$. Ciprofloxacin has been used as a positive control.

Antifungal Activity For media preparation, $20 \mathrm{~g}$ of PDA was dissolved in $1000 \mathrm{~mL}$ of deionized water and placed in an autoclave along with Petri dishes at $137^{\circ} \mathrm{C}$ for $45 \mathrm{~min}$. The molted PDA was then poured equally and allowed it to cool at room temperature. Then, the wells were made in each Petri dish and the strains of fungi streaks on Petri dishes using sterilized cotton swab. After streaking the samples were used in concentrations of 50, 100, 150 and 200 ppm, respectively, along with control Econazole. Next, each Petri plates was placed in incubator and after 3 days the data was recorded as mycelium inhibition were recorded as diameter in triplicate and data was calculated in mean and SEM. Then, the formula used for calculating percent mycelial inhibition. Percent inhibition of mycelium growth $=(\mathrm{A}-\mathrm{B}) / \mathrm{A} \times 100$, where $\mathrm{A}$ is the mycelium growth in control, and $\mathrm{B}$ is the mycelium growth in test.

The antifungal activity was assayed by disc diffusion method as described by (Ali-Shtayeh \& Abu 1999). The samples of SONPs, Asp-SONPs, Aspirin, PVA-AspSONPs and St-Asp-SONPs were prepared in four different concentrations $(50,100,150,200 \mathrm{mg} / \mathrm{mL})$ and was tested against six fungal strains, Rhizopus nigricans, Curvularia lunata, Aspergillus niger, Helmentiasporium maydis, Alternaria solani and Paecilomyces lilacinusby. Results were reported as mean \pm SEM and percent mycilial growth reduction.

Insecticidal Activity The experiment was performed in clean and sterilized Petri dishes at room temperature. Three different concentrations 10,100 and $1000 \mu \mathrm{L}$ of each sample was used in triplicates in the Petri dishes and evaporated overnight to dry and then added 5 insects of each type Tribolium casterium (corn beetles) and Callosobruchus chinensis (Chick Pea beetles) in their concerned petri dishes though small brush (Velayutham et al. 2013). The whole experiments were kept for $24 \mathrm{~h}$ at room temperature $\left(25-27^{\circ} \mathrm{C}\right)$. After $24 \mathrm{~h}$, the number of dead and live insects were counted in each petri dish and then percent mortality of insects were calculated by the following formula $\%$ [Mortality $=100-$ Number of insects in tests number of insects in negative control $\times 100$ ] (Velayutham et al. 2016).

Phytotoxic Activity The assay is used to check the weedicidal (Herbicidal activity) capability of the test compound against the weeds Lamina minor. The phytotoxicity assay was carried out for SONPS, Aspirin, Asp-SONPS PVA coated and Starch coated compounds. Different concentrations were taken as 10, 100 and $1000 \mu \mathrm{g} / \mathrm{mL}$. Required stock solutions were prepared by dissolving $0.05 \mathrm{~g}$ of each sample of NPs in $5 \mathrm{~mL}$ of deionized water. Three sets of different concentration $(20$,
$200 \& 2000 \mu \mathrm{L}$, respectively) were prepared from each stock solution. Three petri dishes were used to which each concentrated solution was added. The fronds of $L$. minor were added to each petri dish. The amount of fronds was numbered in every petri dish. By applying the same method, the culture sample was tested in the absence of nanoparticles. The result obtained after 4 days were calculated for every petri dishes by noticing change in color and increase in number of fronds. Statistical analysis was done by finding the value of FI50 (Velammal et al. 2016). For $\%$ growth inhibition the following formula was used for calculations:

Percent inhibition $=100-$ No. of fronds in test total number of fronds in control $\times 100$

Anthelmintic Activity The anthelmintic study was performed for aspirin (NSAID) and Asp-SONPs coated with starch and PVA. Different concentrations were prepared as per protocol i-e 30, 300 and 3000 ppm. Formulation of stock solution for each of the samples was done by weighing $0.05 \mathrm{~g}$ of the sample and dissolving it in $5 \mathrm{~mL}$ of de-ionized water. Three petri dishes along with $30 \mathrm{~mL}$ of tap water were used for separate stock solutions. Various concentrations of stock solution $(30,300$ and $3000 \mu \mathrm{L}$, respectively) were added to each petri dish. Earth worms of the same length and same number were added to test solutions and starting time was noted. After 10,10... min, results were recorded by noticing any kind of movement by earth worms (paralysis time) until their death time reach. The time duration was recorded by stop watch from start till death of earth worms (El Kassas et al. 2014).

\section{RESULTS AND DISCUSSION}

\section{CHARACTERIZATION}

UV/Visible Spectroscopy From Figure 2(a) - 2(d), it can be concluded that reduction of $\mathrm{Ag}+$ was observed by UV visible spectroscopy. Maximum absorption at $442 \mathrm{~nm}$ confirmed the formation of SONPs. The disappearance of this peak after loading of aspirin indicates its attachment to the surface of silver oxide nano particles. However, no shift was observed in wavelength when Starch and PVA were coated on aspirin loaded silver oxide nano particles (Asp-SONPs). Although appreciable variation in absorbance was observed, this is an evidence of surface interaction of coating material with that of aspirin loaded on silver oxide nanoparticles.

$X$-Ray Spectroscopy The purified SONPs (Figure 3) gave characteristic peaks which confirmed its formation by using X-ray Spectroscopy. For the SONPs two-theta (20), spectrum intense peaks are observed at $28^{\circ}, 35^{\circ}$ and $44^{\circ}$. The adsorption of aspirin on the surface of SONPs was confirmed by appearance of 3 new diffraction two-theta (20) peaks at $15^{\circ}, 23^{\circ}$ and $27^{\circ}$ in the spectra of XRD Figure 4. 


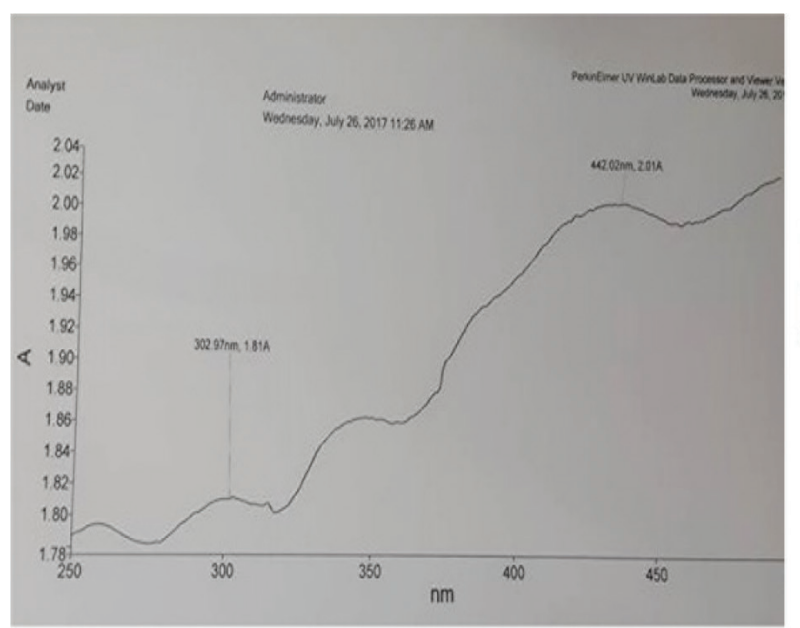

FIGURE 2(a). UV spectra of SONPs

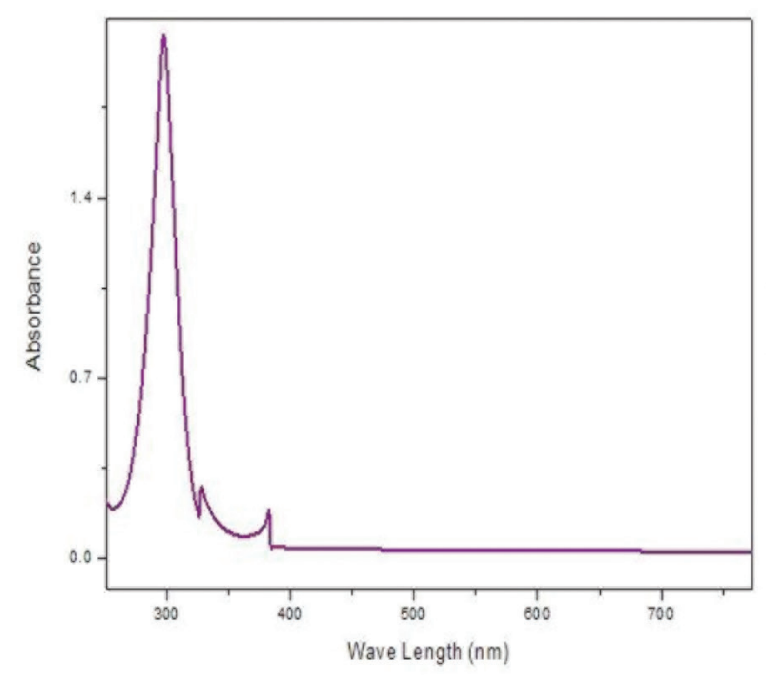

FIGURE 2(c). UV spectra of Asp-SONPs-PVA

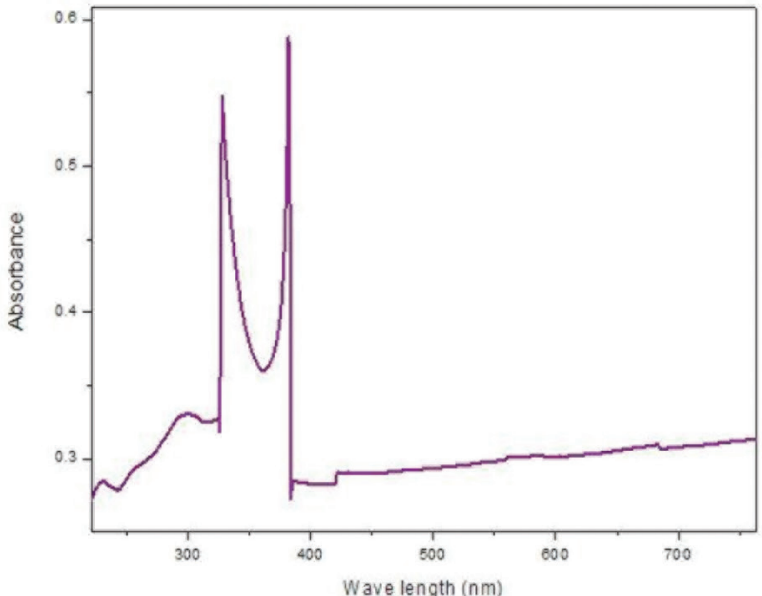

FIGURE 2(b). UV spectra of Asp-SONPs

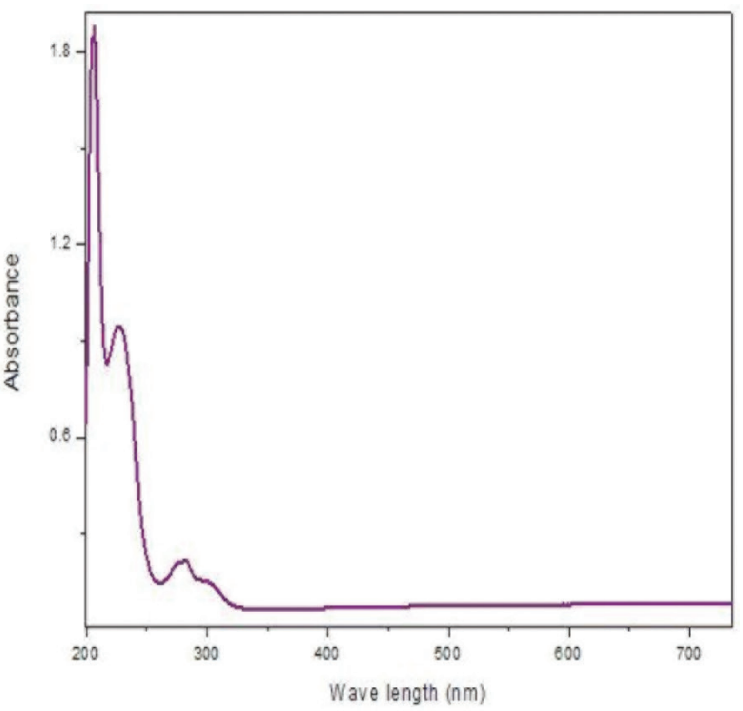

FIGURE 2(d). UV spectra of Asp-SONPs-St

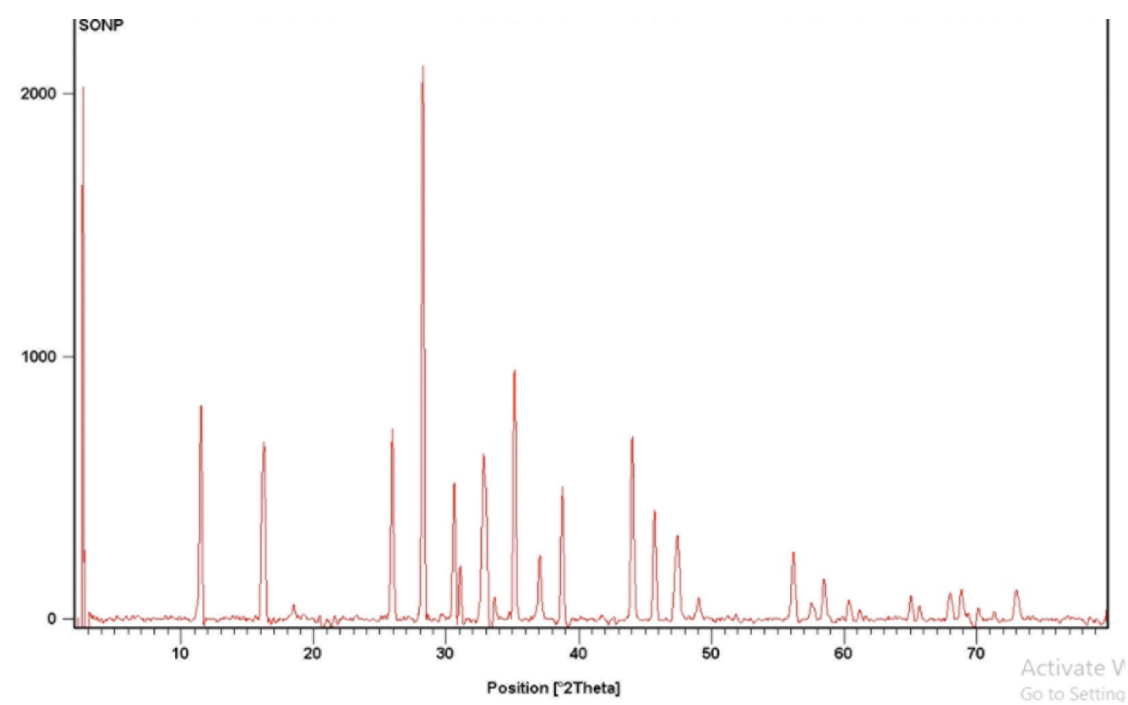

FIGURE 3. XRD spectra of SONPS 


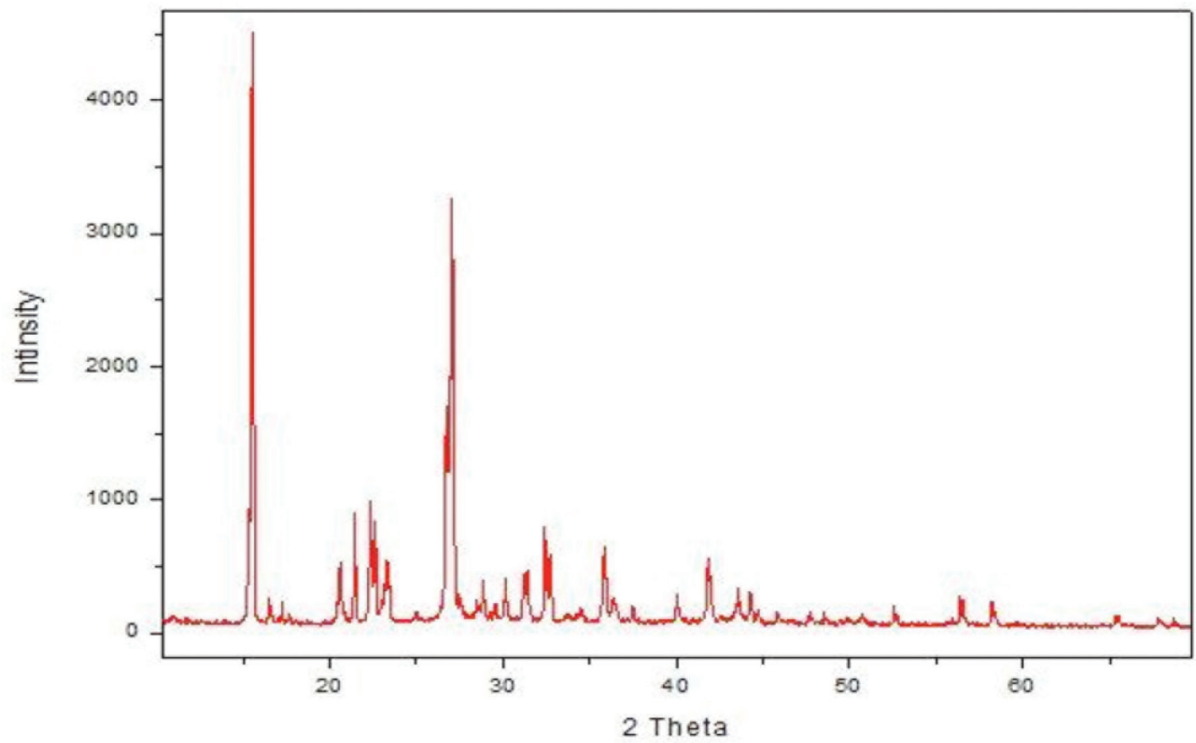

FIGURE 4. XRD spectra of Asp-SONPs

Fourier Transform Infrared (FTIR) Spectroscopy Mode of vibrations helped us determine the characteristic peaks of different functional groups. The FTIR absorption showed various major and minor peaks but the characteristic peak for carbonyl group of carboxylic acid observed at $1679 \mathrm{~cm}^{-1}$ and that of ester at $1747 \mathrm{~cm}^{-1}$ in FT-IR spectra is that of aspirin (Figure 5), while for the hydroxyl (-OH) stretching of carboxylic acid the peak was observed in the region $2700-3300 \mathrm{~cm}^{-1}$. When aspirin laden on silver oxide nano particles the disappearance of hydroxyl and carbonyl peaks) was noticed which shows that the carbonyl group chelated to the surface of silver oxide nano-particles (Figure 6) (Siddiqui et al. 2013).

This further confirms the formation of SONPs.

\section{BIOLOGICAL ACTIVITIES}

Antibacterial Activity The synthesized nano-particles exhibited good activity against both gram positive as well as gram negative bacteria. The difference between the activities of the two is attributed to the difference in cell wall composition/different membrane structures of the two. Thick peptidoglycan $(30 \mathrm{~nm})$ of gram positive bacteria is difficult to penetrate by the synthesized NP as compared to thinner peptidoglycan $(\sim 2-3 \mathrm{~nm})$ of gram negative (Morones et al. 2005). Previous finding showed that in the case of $E$. coli changes in the cell wall composition increase its permeability and effect proper transport through plasma membrane (Sondi et al. 2004). Besides its cell wall composition, there are other factors which are related to its activity and the mode of action such as physiology,

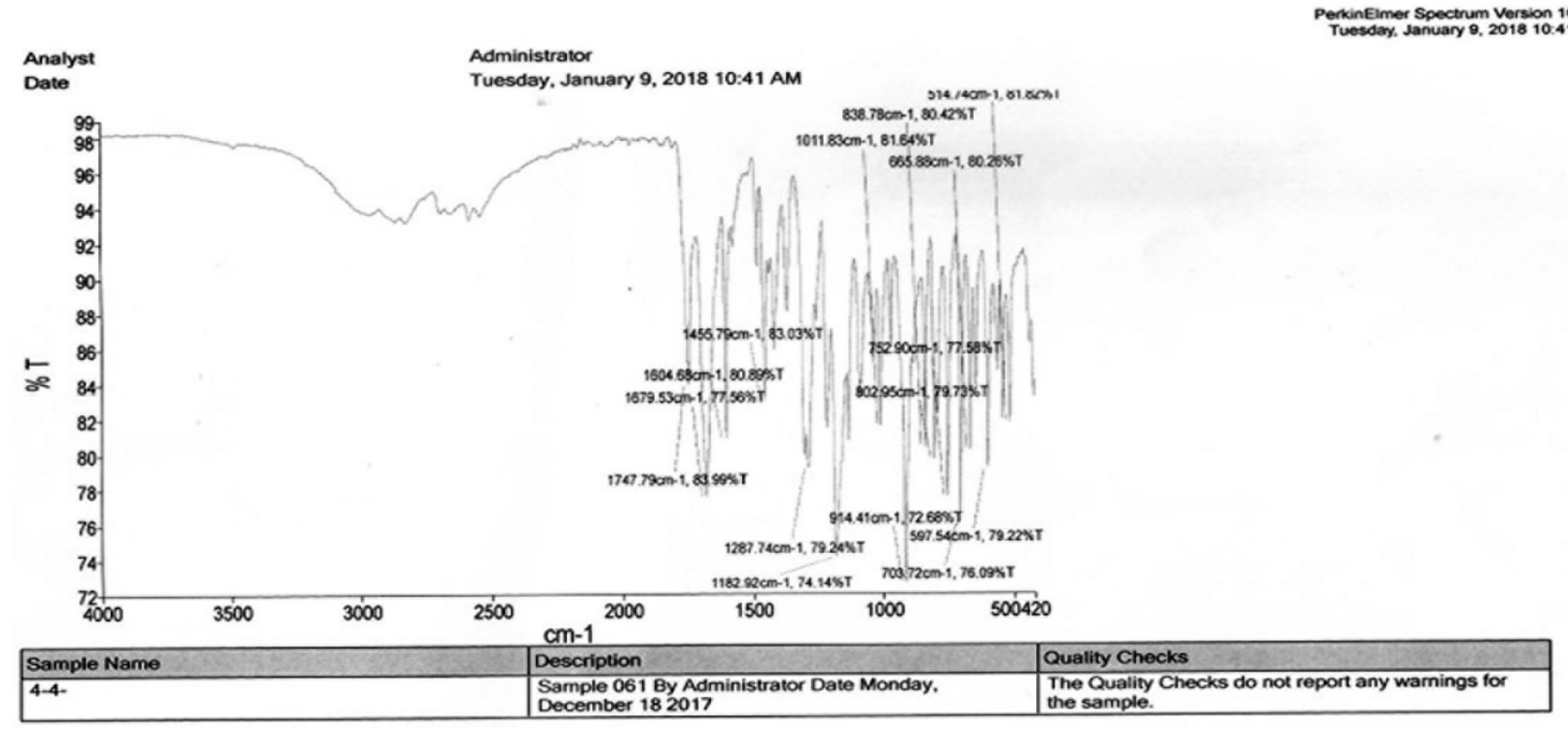

FIGURE 5. FT-IR spectrum of aspirin 


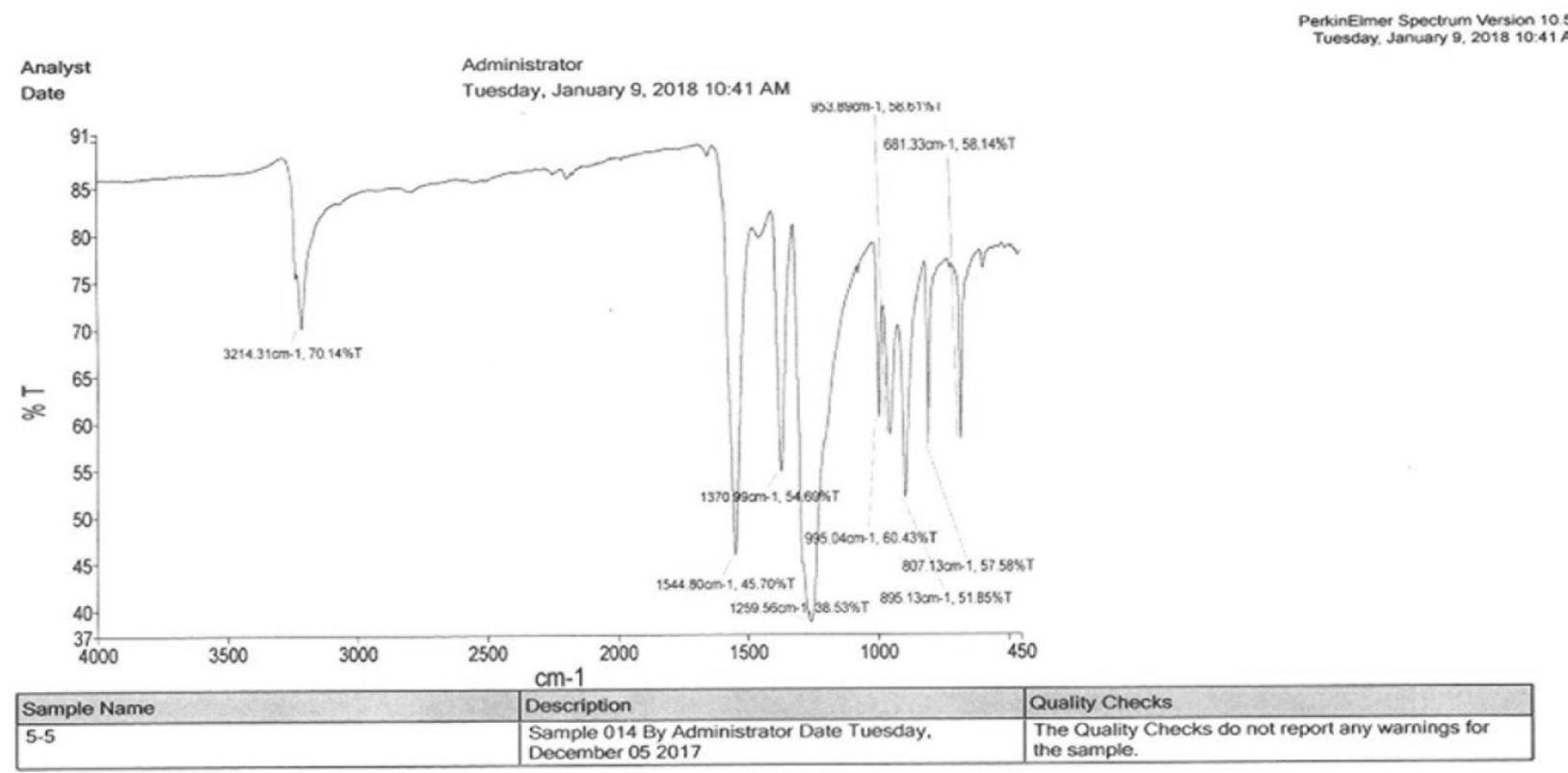

FIGURE 6. FT-IR spectrum of Asp-SONP

metabolism and their interaction with the charged silver nanoparticles. However, it is believed to operate by two possible bactericidal mechanisms, either there exists an electrostatic attraction between negatively charged cell membrane of the microorganisms and the positively charged Ag. Secondly, the formation of pits in the cell wall of bacteria which in turn is related to the concentration of Ag used (Bindhu et al. 2015). Bacteria overall is negative charge due to excessive dissociation of functional groups like carboxylic acid. One report suggests that bacteria lose its ability for DNA replication once treated with silver ions (Morones et al. 2005). Due to these reasons, it suggests that it is a dose dependent mechanism where the effect was more prevalent on gram negative microorganisms. Antibacterial activity was quantitatively assayed for 50-200 $\mathrm{ug} / \mathrm{mL}$ concentrations. All nanoparticles synthesized were effectively inhibiting the bacteria at all concentrations. When $200 \mathrm{ug} / \mathrm{mL}$ of Asp-SONPS-PVA was used it showed highest antibacterial activity with maximum percent inhibition of 70\% followed by Asp-SONPs-St whereas the Asp-SONPs and aspirin showed similar moderate activity. As expected, no zone of inhibition was observed for the control. The SONPs showed lowest antibacterial activity, compared with standard against all bacterial strains. Zone of inhibition of each of bacterium is illustrated below in the Table 1 . The present study clearly indicates that Silver oxide nanoparticle can act as effective antibacterial agent against all bacterial strains.

Antifungal Activity The MIC for all species of fungal strains was determined using disc diffusion method. There have been several reports suggesting the antifungal activity of nanoparticles where the mechanism is mainly associated with the attack of AgNPs on the cell membrane of the fungus which results in pits, pores and ultimately cell death. Using the same mechanism Dermatophytes fungi, biofilms of sessile cells of C.albicans and C. glabrata and Candida spp. have been successfully stopped from having antifungal activity by different research groups (Dhoondia et al. 2012). Result of our synthesized NPs shows that Asp-SONPs-PVA was most effective against all test strains having highest percent inhibition of $75 \%$ followed by AspSONPS-St showing highest percent inhibition of $69 \%$. The moderate activity was noticed for Asp-SONPs and Aspirin. The results for SONPs showed lowest effect among the five samples with $39 \%$. The overall result is mentioned in Table 2.

Phytotoxic Activity The overall profile suggests no significant activity for the test compound at all the applied concentrations. However, when test compound Asp-SONPs was subjected to allelopathy against Lamina minor, the $\%$ inhibition was 53 to 55 for 10 and 1000 $\mu \mathrm{g} / \mathrm{mL}$, respectively. The results for SONPs $\%$ inhibition range from 40 to $42 \%$ with FI5082.1571. The activities were further enhanced when tested against PVA coated SONPs. It was 59.5 for 10 ppm, 65.9 for 1000 ppm (Table 2.1). The results were very encouraging when compared with documented literature (Moukrad et al. 2014). The allelopathy assay of starch coated products showed a \% inhibition from 61.7 to 63.8 for test compounds having concentrations 10,100 and $1000 \mu \mathrm{g} / \mathrm{mL}$. The overall results for phytotoxicity suggests that PVA coated SONPs exhibits significant activities compounds to the test samples in the same set of experiment. Some interesting allele chemicals can be formulated for PVA coated SONPs.

Insecticidal Activity The insecticidal activity of the synthesized coated samples was determined using weevils (Alaqad et al. 2016). The insecticidal activity of SONPs, 
TABLE 1. Evaluation of antibacterial activity

\begin{tabular}{|c|c|c|c|c|c|c|c|}
\hline Treatment & Dosage & E. coli & S. aureus & $\begin{array}{l}\text { Proteus } \\
\text { vulgaris }\end{array}$ & $\begin{array}{c}\text { Citrobacter } \\
\text { freundii }\end{array}$ & $\begin{array}{c}\text { Enterobacte } \\
\text { raerogenes }\end{array}$ & V.cholera \\
\hline \multicolumn{2}{|c|}{ Ciprofloxacin (control) } & 31 & 32 & 30 & 30 & 37 & 30 \\
\hline \multirow[t]{4}{*}{ SONPS } & $50 \mu \mathrm{g} / \mathrm{mL}$ & $8 \pm 0.57$ & $10 \pm 1.54$ & $8 \pm 1.1$ & $9 \pm 1.0$ & $9 \pm 1.0$ & $10 \pm 1.0$ \\
\hline & $100 \mu \mathrm{g} / \mathrm{mL}$ & $10 \pm 1.73$ & $11 \pm 0.57$ & $10 \pm 1.54$ & $11 \pm 0.57$ & $12 \pm 1.52$ & $12 \pm 1.52$ \\
\hline & $150 \mu \mathrm{g} / \mathrm{mL}$ & $12 \pm 1.54$ & $13 \pm 1.15$ & $12 \pm 0.57$ & $12 \pm 1.52$ & $13 \pm 1.52$ & $14 \pm 0.57$ \\
\hline & $200 \mu \mathrm{g} / \mathrm{mL}$ & $13 \pm 0.57$ & $14 \pm 1.0$ & $13 \pm 1.15$ & $13 \pm 0.57$ & $14 \pm 1.0$ & $15 \pm 1.52$ \\
\hline \multirow[t]{4}{*}{ Asp-SONPs } & $50 \mu \mathrm{g} / \mathrm{mL}$ & $11 \pm 1.52$ & $10 \pm 0.57$ & $11 \pm 0.57$ & $11 \pm 1.52$ & $12 \pm 0.57$ & $10 \pm 1.0$ \\
\hline & $100 \mu \mathrm{g} / \mathrm{mL}$ & $13 \pm 1.15$ & $12 \pm 1.54$ & $12 \pm 0.57$ & $13 \pm 1.0$ & $14 \pm 1.52$ & $12 \pm 0.57$ \\
\hline & $150 \mu \mathrm{g} / \mathrm{mL}$ & $15 \pm 2.5$ & $14 \pm 3.60$ & $15 \pm 2.5$ & $14 \pm 1.52$ & $15 \pm 1.0$ & $15 \pm 1.52$ \\
\hline & $200 \mu \mathrm{g} / \mathrm{mL}$ & $16 \pm 1.52$ & $15 \pm 1.0$ & $16 \pm 1.52$ & $14 \pm 0.57$ & $15 \pm 0.28$ & $16 \pm 1.0$ \\
\hline \multirow{4}{*}{$\begin{array}{l}\text { Aspirin } \\
\text { (Pure form) }\end{array}$} & $50 \mu \mathrm{g} / \mathrm{mL}$ & $11 \pm 0.57$ & $12 \pm 0.57$ & $8 \pm 0.57$ & $9 \pm 1.0$ & $8 \pm 1.15$ & $11 \pm 1.52$ \\
\hline & $100 \mu \mathrm{g} / \mathrm{mL}$ & $12 \pm 0.57$ & $15 \pm 2.5$ & $10 \pm 1.0$ & $11 \pm 0.57$ & $10 \pm 1.0$ & $13 \pm 1.15$ \\
\hline & $150 \mu \mathrm{g} / \mathrm{mL}$ & $14 \pm 3.60$ & $16 \pm 1.52$ & $12 \pm 1.54$ & $12 \pm 1.52$ & $12 \pm 0.57$ & $15 \pm 1.0$ \\
\hline & $200 \mu \mathrm{g} / \mathrm{mL}$ & $17 \pm 0.57$ & $17 \pm 0.57$ & $13 \pm 1.15$ & $16 \pm 1.15$ & $16 \pm 0.57$ & $16 \pm 0.28$ \\
\hline \multirow{4}{*}{ Asp-SONPs-PVA } & $50 \mu \mathrm{g} / \mathrm{mL}$ & $15 \pm 2.5$ & $16 \pm 1.15$ & $13 \pm 0.57$ & $15 \pm 1.52$ & $14 \pm 0.57$ & $16 \pm 0.28$ \\
\hline & $100 \mu \mathrm{g} / \mathrm{mL}$ & $17 \pm 0.57$ & $17 \pm 0.57$ & $16 \pm 1.15$ & $16 \pm 0.28$ & $17 \pm 0.57$ & $17 \pm 1.73$ \\
\hline & $150 \mu \mathrm{g} / \mathrm{mL}$ & $18 \pm 1.52$ & $20 \pm 0.56$ & $17 \pm 0.57$ & $19 \pm 1.73$ & $19 \pm 1.73$ & $19 \pm 1.73$ \\
\hline & $200 \mu \mathrm{g} / \mathrm{mL}$ & $21 \pm 0.57$ & $22 \pm 1.0$ & $20 \pm 2.64$ & $21 \pm 0.57$ & $20 \pm 1.0$ & $21 \pm 1.15$ \\
\hline \multirow[t]{4}{*}{ Asp-SONPs-St } & $50 \mu \mathrm{g} / \mathrm{mL}$ & $14 \pm 0.57$ & $13 \pm 0.57$ & $12 \pm 1.0$ & $14 \pm 0.57$ & $15 \pm 0.57$ & $16 \pm 0.28$ \\
\hline & $100 \mu \mathrm{g} / \mathrm{mL}$ & $16 \pm 1.15$ & $16 \pm 1.15$ & $15 \pm 1.52$ & $17 \pm 0.57$ & $16 \pm 0.28$ & $18 \pm 1.0$ \\
\hline & $150 \mu \mathrm{g} / \mathrm{mL}$ & $17 \pm 0.57$ & $18 \pm 0.57$ & $18 \pm 0.57$ & $18 \pm 0.57$ & $18 \pm 0.57$ & $19 \pm 1.73$ \\
\hline & $200 \mu \mathrm{g} / \mathrm{mL}$ & $20 \pm 0.57$ & $19 \pm 2.64$ & $19 \pm 1.0$ & $20 \pm 1.0$ & $20 \pm 1.0$ & $20 \pm 0.57$ \\
\hline
\end{tabular}

TABLE 2. Evaluation of antifungal activity

\begin{tabular}{|c|c|c|c|c|c|c|c|}
\hline Treatment & Dosage & A. Niger & A. solani & H. maydis & R. nigricans & B. lunata & P. lilacinus \\
\hline \multicolumn{2}{|c|}{ Econazole (control) } & 33 & 29 & 31 & 31 & 29 & 28 \\
\hline \multirow[t]{4}{*}{ SONPS } & $50 \mu \mathrm{g} / \mathrm{mL}$ & $10 \pm 0.57$ & $11 \pm 0.57$ & $9 \pm 1.52$ & $9 \pm 0.57$ & $10 \pm 1.0$ & $11 \pm 1.0$ \\
\hline & $100 \mu \mathrm{g} / \mathrm{mL}$ & $12 \pm 0.57$ & $14 \pm 1.0$ & $11 \pm 1.0$ & $10 \pm 1.0$ & $11 \pm 1.15$ & $13 \pm 1.52$ \\
\hline & $150 \mu \mathrm{g} / \mathrm{mL}$ & $14 \pm 2.88$ & $15 \pm 2.5$ & $13 \pm 0.57$ & $12 \pm 0.57$ & $13 \pm 1.0$ & $14 \pm 0.57$ \\
\hline & $200 \mu \mathrm{g} / \mathrm{mL}$ & $15 \pm 1.0$ & $15 \pm 0.28$ & $14 \pm 2.88$ & $14 \pm 1.0$ & $13 \pm 1.52$ & $15 \pm 2.08$ \\
\hline \multirow[t]{4}{*}{ Asp-SONPs } & $50 \mu \mathrm{g} / \mathrm{mL}$ & $12 \pm 0.57$ & $12 \pm 0.57$ & $11 \pm 1.0$ & $10 \pm 1.52$ & $11 \pm 1.0$ & $12 \pm 1.0$ \\
\hline & $100 \mu \mathrm{g} / \mathrm{mL}$ & $14 \pm 2.88$ & $14 \pm 2.88$ & $13 \pm 0.57$ & $12 \pm 0.57$ & $12 \pm 0.57$ & $14 \pm 0.57$ \\
\hline & $150 \mu \mathrm{g} / \mathrm{mL}$ & $15 \pm 2.5$ & $15 \pm 2.5$ & $14 \pm 2.88$ & $14 \pm 1.0$ & $14 \pm 0.57$ & $15 \pm 2.88$ \\
\hline & $200 \mu \mathrm{g} / \mathrm{mL}$ & $17 \pm 0.57$ & $17 \pm 0.57$ & $16 \pm 0.28$ & $15 \pm 1.0$ & $16 \pm 1.0$ & $16 \pm 2.08$ \\
\hline \multirow{4}{*}{$\begin{array}{l}\text { Aspirin } \\
\text { (Pure form) }\end{array}$} & $50 \mu \mathrm{g} / \mathrm{mL}$ & $11 \pm 1.0$ & $10 \pm 1.0$ & $11 \pm 0.57$ & $8 \pm 1.0$ & $8 \pm 1.15$ & $9 \pm 0.57$ \\
\hline & $100 \mu \mathrm{g} / \mathrm{mL}$ & $12 \pm 0.57$ & $12 \pm 0.57$ & $12 \pm 1.0$ & $9 \pm 0.57$ & $10 \pm 1.52$ & $10 \pm 1.52$ \\
\hline & $150 \mu \mathrm{g} / \mathrm{mL}$ & $13 \pm 0.57$ & $14 \pm 2.88$ & $14 \pm 2.88$ & $13 \pm 1.15$ & $11 \pm 0.57$ & $12 \pm 0.57$ \\
\hline & $200 \mu \mathrm{g} / \mathrm{mL}$ & $15 \pm 2.5$ & $16 \pm 2.5$ & $16 \pm 0.28$ & $15 \pm 2.88$ & $14 \pm 1.0$ & $16 \pm 2.88$ \\
\hline \multirow{4}{*}{$\begin{array}{l}\text { Asp-SONPs- } \\
\text { PVA }\end{array}$} & $50 \mu \mathrm{g} / \mathrm{mL}$ & $16 \pm 0.5$ & $17 \pm 1.15$ & $18 \pm 0.57$ & $16 \pm 2.51$ & $16 \pm 0.7$ & $16 \pm 0.57$ \\
\hline & $100 \mu \mathrm{g} / \mathrm{mL}$ & $19 \pm 0.57$ & $18 \pm 0.57$ & $20 \pm 0.57$ & $18 \pm 1.0$ & $17 \pm 2.51$ & $17 \pm 1.0$ \\
\hline & $150 \mu \mathrm{g} / \mathrm{mL}$ & $20 \pm 1.0$ & $20 \pm 1.52$ & $21 \pm 1.52$ & $20 \pm 0.57$ & $19 \pm 1.0$ & $19 \pm 0.57$ \\
\hline & $200 \mu \mathrm{g} / \mathrm{mL}$ & $22 \pm 1.15$ & $21 \pm 1.52$ & $22 \pm 0.57$ & $21 \pm 1.0$ & $21 \pm 0.57$ & $21 \pm 1.0$ \\
\hline \multirow{4}{*}{$\begin{array}{l}\text { Asp-SONPs- } \\
\text { St }\end{array}$} & $50 \mu \mathrm{g} / \mathrm{mL}$ & $15 \pm 0.57$ & $16 \pm 0.5$ & $15 \pm 1.0$ & $15 \pm 0.57$ & $15 \pm 1.15$ & $14 \pm 1.15$ \\
\hline & $100 \mu \mathrm{g} / \mathrm{mL}$ & $17 \pm 1.0$ & $17 \pm 1.0$ & $17 \pm 1.52$ & $17 \pm 0.57$ & $16 \pm 0.57$ & $15 \pm 2.51$ \\
\hline & $150 \mu \mathrm{g} / \mathrm{mL}$ & $18 \pm 0.57$ & $19 \pm 0.57$ & $19 \pm 0.57$ & $18 \pm 1.0$ & $19 \pm 1.0$ & $17 \pm 1.0$ \\
\hline & $200 \mu \mathrm{g} / \mathrm{mL}$ & $21 \pm 1.52$ & $20 \pm 0.57$ & $20 \pm 1.0$ & $20 \pm 0.57$ & $20 \pm 0.57$ & $19 \pm 0.57$ \\
\hline
\end{tabular}


TABLE 2.1. Phytotoxic activity of Lamina minor

\begin{tabular}{|c|c|c|c|c|c|}
\hline Samples & $\begin{array}{l}\text { Concentration } \\
(\mu \mathrm{g} / \mathrm{mL})\end{array}$ & $\begin{array}{c}\text { Number of fronds } \\
\text { in test }\end{array}$ & $\begin{array}{l}\text { Number of fronds in } \\
\text { control }\end{array}$ & Percent Inbhibition & $\mathrm{FI}_{50}$ \\
\hline \multirow[t]{3}{*}{ SONPS } & 10 & 28 & & 40.4 & \\
\hline & 100 & 27 & 47 & 42.55 & 82.1571 \\
\hline & 1000 & 27 & & 42.55 & \\
\hline \multirow[t]{3}{*}{ ASPIRIN } & 10 & 29 & & 38.2 & \\
\hline & 100 & 27 & 47 & 42.5 & 275.1894 \\
\hline & 1000 & 26 & & 44.6 & \\
\hline \multirow[t]{3}{*}{ Asp.SONPs } & 10 & 22 & & 53.1 & \\
\hline & 100 & 22 & 47 & 53.1 & 70.0187 \\
\hline & 1000 & 21 & & 55.3 & \\
\hline \multirow[t]{3}{*}{ PVA coated } & 10 & 19 & & 59.5 & \\
\hline & 100 & 17 & 47 & 63.8 & 186.0747 \\
\hline & 1000 & 16 & & 65.9 & \\
\hline \multirow[t]{3}{*}{ STARCH Coated } & 10 & 18 & & 61.7 & \\
\hline & 100 & 17 & 47 & 63.8 & 467.9244 \\
\hline & 1000 & 17 & & 63.8 & \\
\hline
\end{tabular}

Aspirin, Asp-SONPs, Asp-SONPs- PVA and Asp-SONPs- St, was carried out against $T$. castanium (corn beetles) and C. chinensis (Wheat beetles) (Dinesh et al. 2015). The result was summarized in Table 2.2. Five samples in three different concentrations were used which exhibited a dose dependent activity where both the test insects and their effect increased with increasing concentration. Against both the tested insects Asp-SONPS-PVA showed a highest activity having $\mathrm{LC}_{50}$ value 15.917 and 37.6365 and highest percent mortality at $1000 \mathrm{ppm} 67 \%$, and $73 \%$ followed by St-Asp-SONPs against both the tested insects which showed good result with $\mathrm{LC}_{50} 79.3444$, and 95.0664 where the other three Asp-SONPs, SONPs, and Asp showed less activity as compared to the Asp-SONPs-PVA and Asp-SONPs-St. LC ${ }_{50}$ and percentage mortality values against both the insects for Asp-SONPs 234369.7848, and 2699.360 having percent mortality $13 \%, 20 \%$, and $33 \%$ and for the second tested insect $13 \%, 33 \%$, and $40 \%$ while $0 \%, 7 \%, 20 \%$ and $7 \%$, $13 \%, 33 \%$ noticed for SONPs with $\mathrm{LC}_{50} 1538.5142$ and 451337003 among the all five samples the lowest activity showed by Asp opposed both the insects with $\mathrm{LC}_{50}$ values 509.1707 and 2603.1028 having percentage mortality $0 \%, 7 \%, 13 \%, 0 \%, 13 \%$, and $27 \%$, respectively (Ullah et al. 2013).

Table 2.3 shows that aspirin at concentration of 30 , $300,3000 \mathrm{ppm}$ after $10 \mathrm{~min}$ out of total of 15 test species 7,9 , and 11 paralyzed while none 7 to 9 died after $2 \mathrm{~h}$, respectively. Asp-SONPs starch coated results are most promising at concentration of 30,300 and $3000 \mathrm{ppm}$ where the entire test species paralyzed while 9, 10, and 11 died, respectively. The results are encouraging when compared with documented data (Priya et al. 2015).

Asp-SONPs coated PVA at 30 ppm, 14 paralyzed while 11 died at the same concentration. At $30 \mathrm{ppm} 15$ paralyzed and 13 died after $10 \mathrm{~min}$ and $2 \mathrm{~h}$, respectively. Outstanding results achieved at concentration $3000 \mathrm{ppm}$ where all the result species paralyzed and 14 died in due protocol time.
We have successfully employed a simple, cheap and realiable method for the synthesis of pharmacologically important AgNPS, AgONPs and AsAgONPs which was indicated/ corroborated by the appearance of brown color attributed to the excitation of surface plasmon resonance. Synthesized nanoparticles are evaluated by spectroscopic techniques. The characteristic peak at $442 \mathrm{~nm}$ confirmed the formation of SONPs. AgNO3 has successfully been reduced from Ag+ to Ago confirmed by UV visible spectroscopy. XRD confirmed the purity of the samples and the formation of two new thetas confirmed the aspirin formation while the FTIR absorption gave information regarding the functional groups involved during the synthesis process. Carbonyl group chelated to the surface of silver oxide nano particles which supports the claims by Siddiqui et al. (2013). Silver is known antimicrobial agent. Silver compounds being toxic to microbes displayed strong antibacterial activity against synthesized nanoparticles. Antibacterial assay confirmed its potential use as an antibacterial agent. This provides solid evidence that it can be effectively used as an antibacterial agent. Mechanism of silver to act on bacterium is yet to be understood, however, it is believed to be attributed to the fact that silver tends to adsorb to the bacterial surface which resist dehydrogenation and possible catalytic oxidation of cell membrane which leads to cell death. Recently there has been a report suggesting chelation of silver which unwinds tDNA and leads to antimicrobial activity. The synthesized nanoparticle displayed better antimicrobial activity against bacteria and fungi then the NSAIDS aspirin and the control groups used. Silver nanoparticles are toxic at high concentrations therefore its use at low concentration is beneficial for health. Lower MIC value of SONP against gram positive and gram negative bacterium is of importance and can be potentially exploited as an antibacterial agent antioxidants are important in human health and food. 


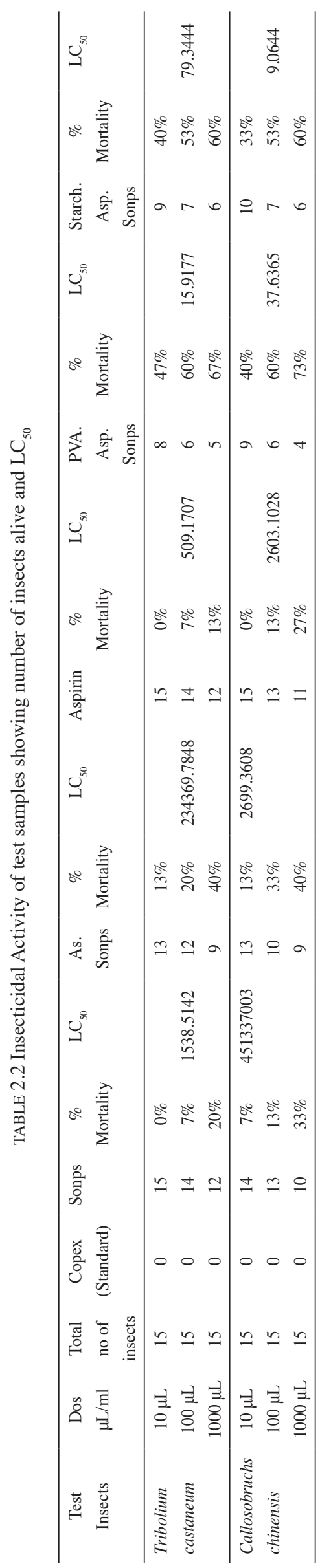


TABLE 2.3. Anthelmentic activities

\begin{tabular}{lcccc}
\hline Nanoparticles & $\begin{array}{c}\text { Conc; } \\
(\text { PPM })\end{array}$ & $\begin{array}{c}\text { No; } \\
\text { of test species }\end{array}$ & $\begin{array}{c}\text { Paralysis after } \\
10 \mathrm{~min}\end{array}$ & $\begin{array}{c}\text { Time to die } \\
\text { after } 2 \mathrm{~h}\end{array}$ \\
\hline Aspirin & 30 & 15 & 7 & 0 \\
& 300 & 15 & 9 & 7 \\
& 3000 & 15 & 11 & 9 \\
Asp-SONP (st) & 30 & 15 & 15 & 9 \\
& 300 & 15 & 15 & 10 \\
Asp-SONP (PVA) & 3000 & 15 & 15 & 11 \\
& 30 & 15 & 14 & 13 \\
& 300 & 15 & 15 & 14 \\
\hline
\end{tabular}

Antioxidant activity of As-SONP was compared with DPPH (diphenylpicrylhydrazyl) which indicated its powerful reducing ability. Asp-SONP at $50 \mathrm{ppm}$ can be used as a good antioxidant agent. SONPs were also evaluated for its cytotoxic activity. Cytotoxic effect along with mortality rate allowed us to predict its potential use as an anticancer agent. Asp-SONPS-PVA with LD5055 and percent mortality of $70 \%$ at $1000 \mathrm{ppm}$ displayed efficient result with possible promising future. Insecticidal activity showed good results for all the synthesized NPs with an exception of aspirin. Significant results were obtained when AspSONPs tested for its phytotoxic activity. Asp-SONPs coated PVA tested for antithelmic activity showed good results by either stunning or killing the parasite, earthworm at a concentration of $3000 \mathrm{ppm}$.

\section{CONCLUSION}

In an attempt to find the less expensive, cost effective and simple approach for the synthesis of pharmacologically important nanoparticle, we have demonstrated the rapid, stable synthesis of silver oxide nano particles loaded with aspirin. For the characterization, UV/Vis, FT-IR, and XRD techniques were used. The present study showed that the synthesized nano particles are considered to be the most effective as cytotoxic, insecticidal, phytotoxic, antioxidant, anthelmintic and antimicrobial agents. Besides this, for further evaluation in silico and in vivo studies are recommended.

\section{ACKNOWLEDGEMENTS}

The authors extend their appreciation to the Deanship of Scientific Research at King Saud University for funding support (research group no. RGP- 1440-009).

\section{REFERENCES}

Ahmad, S., Ullah, R., Naser M. AbdElsalam, Hassan, F., Ahtaram, B., Muhammad, T.J., Anwar, A.S. \& Muhammad, A. 2014. One new royleanumoate from Teucrium royleanum Wall. ex Benth. The Scientific World Journal 2014: 581629.

Alaqad, K. \& Saleh, T.A. 2016. Gold and silver nanoparticles: Synthesis methods, characterization routes and applications towards drugs. J. Environ. Anal. Toxicol. 6: 384.
Ali-Shtayeh, M. \& Abu, G.S.I. 1999. Antifungal activity of plant extracts against dermatophytes. Mycoses 42(11-12): 665-672.

Balouiri, M., Sadiki, M. \& Ibnsouda, S.K. 2016. Methods for in vitro evaluating antimicrobial activity: A review. Journal of Pharmaceutical Analysis 6(2): 71-79.

Bindhu, M. \& Umadevi, M. 2015. Antibacterial and catalytic activities of green synthesized silver nanoparticles. Spectrochimica Acta Part A: Molecular and Biomolecular Spectroscopy 135: 373-378.

Chiguvare, H., Opeoluwa, O.O., Reuben, M., Olukayode, A., Idris, A.O., Adebola, O.O., Benedicta, N.N., Sandile, P.S., Sneha, M. \& Oluwatobi, S.O. 2016. Synthesis of silver nanoparticles using buchu plant extracts and their analgesic properties. Molecules 21: 774.

Choi, J.S., Lee, H., Park, Y.K., Kim, S.J., Kim, B.J., An, K.H., Kim, B.H. \& Jung, S.C. 2016. Application of silver and silver oxide nanoparticles impregnated on activated carbon to the degradation of bromate. Journal of Nanoscience and Nanotechnology 16(5): 4493-4497.

Dhoondia,Z.H. \& Chakraborty, H. 2012. Lactobacillus mediated synthesis of silver oxide nanoparticles. Nanomaterials and Nanotechnology https://doi.org/10.5772/55741.

Dinesh, D., Murugan, K., Madhiyazhagan, P., Panneerselvam, C., Kumar, P.M., Nicoletti, M., Jiang, W., Benelli, G., Chandramohan, B. \& Suresh, U. 2015. Mosquitocidal and antibacterial activity of green-synthesized silver nanoparticles from Aloe vera extracts: Towards an effective tool against the malaria vector Anopheles stephensi? Parasitology Research 114(4): 1519-1529.

El Kassas, H.Y. \& Attia, A.A. 2014. Bactericidal application and cytotoxic activity of biosynthesized silver nanoparticles with an extract of the red seaweed Pterocladiella capillacea on the HepG2 cell line. Asian Pac. J. Cancer Prev. 15(3): 1299-1306.

Fang, J., Zhong, C. \& Mu, R. 2005. The study of deposited silver particulate films by simple method for efficient SERS. Chemical Physics Letters 401: 271-275.

Galya, T., Vladimir, S., Ivo, K., Radko, N., Jana, S. \& Petr, S. 2008. Antibacterial poly (vinyl alcohol) film containing silver nanoparticles: Preparation and characterization. Journal of Applied Polymer Science 110(5): 3178-3185.

Gurunathan, S., Han, J.W., Eppakayala, V., Jeyaraj, M. \& Kim, J.H. 2013. Cytotoxicity of biologically synthesized silver nanoparticles in MDA-MB-231 human breast cancer cells. BioMed Research International 2013: 535796.

Hosseinpour-Mashkani, S.M. \& Ramezani, M. 2014. Silver and silver oxide nanoparticles: Synthesis and characterization by thermal decomposition. Materials Letters 130: 259-262. 
Morones, J.R., Jose, L.E., Alejandra, C., Katherine, H., Juan, B.K., Jose, T.R.I. \& Miguel, J.Y. 2005. The bactericidal effect of silver nanoparticles. Nanotechnology 16(10): 2346-2353.

Moukrad, N., Fouzia, R.F., Ikram, D. \& Omar,Z.2014. Phytotoxic activity of the zinc oxyde nanoparticles synthesized from different precursors on germination and radicle growth of seeds Lepidium sativum. International Journal of Scientific and Research Publications 4(12): 1-6.

Priya, S. \& Santhi, S. 2015. Biosynthesis and in vitro anthelmintic activity of silver nanoparticles using aqueous leaf extracts of Azadirachta indica. World Journal of Pharmacy and Pharmaceutical Sciences 4(10): 2105-2116.

Rafique, M., Sadaf, I., Shahid Rafique, M. \& Bilal Tahir, M. 2016. A review on green synthesis of silver nanoparticles and their applications. Artificial Cells, Nanomedicine, and Biotechnology 45(7): 1272-1291.

Siddiqui, M.R.H., Adil, S.F., Assal, M.E., Roushown, Ali. \& AlWarthan, A. 2013. Synthesis and characterization of silver oxide and silver chloride nanoparticles with high thermal stability. Asian J. Chem. 25(6): 3405-3409.

Sondi, I. \& Salopek-Sondi, B. 2004. Silver nanoparticles as antimicrobial agent: A case study on E. coli as a model for Gram-negative bacteria. Journal of Colloid and Interface Science 275(1): 177-182.

Sudha, A., Jeyakanthan, J. \& Srinivasan, P. 2017. Green synthesis of silver nanoparticles using Lippia nodiflora aerial extract and evaluation of their antioxidant, antibacterial and cytotoxic effects. Resource-Efficient Technologies 3(4): 506-515.

Ullah, S., Ibrar, M. \& Muhammad, N. 2013. Pharmacognostic, larvicidal and phytotoxic profile of Coleus forskohlii and Rosmarinus officinalis. Journal of Pharmacognosy and Phytotherapy 5(4): 59-63.

Velammal, S.P., Devi, T.A.\& Amaladhas, T.P. 2016.Antioxidant, antimicrobial and cytotoxic activities of silver and gold nanoparticles synthesized using Plumbago zeylanica bark. Journal of Nanostructure in Chemistry 6(3): 247-260.

Velayutham, K. \& Ramanibai, R. 2016. Larvicidal activity of synthesized silver nanoparticles using isoamyl acetate identified in Annona squamosa leaves against Aedes aegypti and Culex quinquefasciatus. The Journal of Basic \& Applied Zoology 74: 16-22.

Velayutham, K., Rahuman, A.A., Rajakumar, G., Roopan, S.M., Elango, G., Kamaraj, C., Marimuthu, S., Santhoshkumar, T., Iyappan, M. \& Siva, C. 2013. Larvicidal activity of green synthesized silver nanoparticles using bark aqueous extract of Ficus racemosa against Culex quinquefasciatus and Culex gelidus. Asian Pacific Journal of Tropical Medicine 6(2): 95-101.
Yong, N.L., Ahmad, A. \& Mohammad, A.W. 2013. Synthesis and characterization of silver oxide nanoparticles by a novel method. Int. J. Sci. Eng. Res. 4: 155-158.

Shabir Ahmad, Hira Rashid, Qudisa Jalil, Sidra Munir \& Sulaiman Khan

Department of Chemistry

Islamia College University

Peshawar, KPK

Pakistan

Barkatullah

Department of Botany

Islamia College University

Peshawar, KPK

Pakistan

Riaz Ullah*, Abdelaaty A. Shahat \& Almoqbil A. Naser Abdullah A-Mishari

Medicinal Aromatic and Poisonous Plants Research Centre

College of Pharmacy

King Saud University, Riyadh

Saudi Arabia

Abdelaaty A. Shahat

Department of Phytochemistry

National Research Centre

33 EI Bohouth St.

12622, Dokki, Giza

Egypt

Hafiz M. Mahmood

Department of Pharmacology

College of Pharmacy

King Saud University, Riyadh

Saudi Arabia

Ahmad Bari

Central Lab, College of Pharmacy

King Saud University, Riyadh

Saudi Arabia

*Corresponding author; email: rullah@ksu.edu.sa

Received: 20 January 2019

Accepted: 18 June 2019 